\title{
Anti-proliferative effect of an extract of the root of Polygonum multiflorum Thunb. on MCF-7 human breast cancer cells and the possible mechanisms
}

\author{
HONG-SHENG CHEN ${ }^{1}$, YAN LIU ${ }^{1}$, LUO-QIANG LIN ${ }^{1}$, JIN-LU ZHAO ${ }^{1}$, CHUN-PENG ZHANG $^{1}$, \\ JUN-CHAO JIN $^{1}$, LEI WANG ${ }^{1}$, MING-HAN BAI ${ }^{1}$, YI-CHONG WANG ${ }^{1}$, MING LIU $^{1}$ and BAO-ZHONG SHEN ${ }^{2}$ \\ ${ }^{1}$ Treatment Center of Oncology; ${ }^{2}$ Department of Imaging, The Fourth Affiliated \\ Hospital of Harbin Medical University, Harbin 150001, P.R. China
}

Received May 17, 2011; Accepted August 22, 2011

DOI: $10.3892 / \mathrm{mmr} .2011 .574$

\begin{abstract}
The root of Polygonum multiflorum Thunb. (PM) is utilized to treat many diseases associated with aging. Research also indicates that PM inhibits the proliferation of certain types of cancer cells. The aim of the present study was to evaluate the inhibitory effect of PM extract (PME) on the proliferation of MCF-7 cells and to investigate the underlying mechanisms. Inhibition of the proliferation of MCF-7 cells was determined by the MTT assay. Cell cycle distribution and apoptotic rates were evaluated by flow cytometry, and cell cycle and apoptosis-related protein expression was assessed by Western blotting. Apoptotic characteristics of MCF-7 cells were detected by transmission electron microscopy. The present study showed that PME at doses of 100, 150, 200 and $250 \mu \mathrm{g} / \mathrm{ml}$ significantly inhibited proliferation of MCF-7 cells in a time- and dose-dependent manner. Flow cytometry showed that the cell apoptotic rates were $9.1 \pm 1.67$ and $17.7 \pm 2.93 \%$ after
\end{abstract}

Correspondence to: Dr Ming Liu, Treatment Center of Oncology, The Fourth Affiliated Hospital of Harbin Medical University, NanGang, Harbin 150001, P.R. China

E-mail:mliu35@yahoo.com.cn

Dr Bao-Zhong Shen, Department of Imaging, The Fourth Affiliated Hospital of Harbin Medical University, NanGang, Harbin 150001, P.R. China

E-mail:shenbzh@vip.sina.com

Abbreviations: PME, Polygonum multiflorum Thunb. extract; TCM, traditional Chinese medicine; DMSO, dimethyl sulfoxide; FBS, fetal bovine serum; MTT, 3-(4,5-dimethylthiazol-2-yl)-2,5diphenyltetrazolium bromide; PMSF, phenylmethyl-sulfonyl fluoride; PAGE, polyacrylamide gel electrophoresis; PVDF, polyvinylidene difluoride; TBS, Tris-buffered saline; TEM, transmission electron microscopy; FCM, flow cytometry; Cdks, cyclin-dependent kinases; PP2A, protein phosphatase 2A; PRL-3, phosphatase of regenerating liver-3; PTEN, phosphatase and tensin homologue deleted on chromosome 10; SD, standard deviation

Key words: root of Polygonum multiflorum Thunb. extract, antiproliferation, cell cycle arrest, apoptosis, human breast cancer cells treatment with 100 and $200 \mu \mathrm{g} / \mathrm{ml}$ PME for $48 \mathrm{~h}$, respectively. The proportions of cells in the $\mathrm{G} 2 / \mathrm{M}$ phase were $37.9 \pm 1.47$ and $42.0 \pm 1.71 \%$ after treatment with 100 and $200 \mu \mathrm{g} / \mathrm{ml} \mathrm{PME}$ for $24 \mathrm{~h}$, respectively. Western blot analysis showed that PME down-regulated the protein expression of $\mathrm{Cdc} 25 \mathrm{~B}$ and $\mathrm{Cdc} 25 \mathrm{C}$ phosphatases accompanied by an increase in phospho-Cdk1, and PME promoted cytochrome c release from mitochondria into the cytosol to activate caspase-9. The present study demonstrated that PME inhibited MCF-7 cell proliferation by inducing cell cycle arrest in the $\mathrm{G} 2 / \mathrm{M}$ phase and promoting cell apoptosis. The effects of PME on MCF-7 cells were associated with the modulation of the expression levels of proteins involved in the cell cycle and apoptosis. These data suggest that PME has promise as a treatment against breast cancer by inhibiting the proliferation of cancer cells.

\section{Introduction}

Natural products, which are important sources of medicinal compounds, have been used as drugs to treat many diseases since ancient times. Particularly in the area of cancer, more than $60 \%$ of antitumor medicines on the market are based on natural products (1).

The root of Polygonum multiflorum Thunb. (PM), a perennial vine-like herb, which is called He-shou-wu, has been widely used in traditional Chinese medicine (TCM) as a tonic and anti-aging agent for centuries. Clinically, it has been utilized in the treatment of poliosis, hemopenia, inflammation, bacterial infections, hyperlipidemia, coronary heart disease, neurosis and other diseases commonly associated with aging $(2,3)$. The medicinal effects of PM in the improvement of health conditions are possibly mediated by the antioxidant capacity of this herb (4). The genus PM is the source of a wide range of phenolic compounds, flavonoids, anthraquinones, stilbenes and tannins $(5,6)$. These constituents which possess biological activities in PM are called phytochemicals. Several studies have demonstrated that these phytochemicals from PM display high pharmacological efficiency, such as antioxidant capacity, anti-proliferative, anti-inflammatory, antiviral activies and improvement in learning and memory ability (7-10). Research indicates that PM inhibits the proliferation of certain types of 
carcinoma cells, such as HT29 and SW620 colon cancer cells, and HepG2 human hepatoblastoma cells, but the underlying pharmacological mechanisms are largely unclear (11-13).

Cell cycle is the mechanism through which cells divide, and it is an orderly and tightly regulated phenomenon, including four phases (G1, S, G2 and M). Cancer cells have deregulated cell cycle progression with overexpression of positive regulators and inhibition of negative regulators, giving them unlimited replication potential. Therefore, development of agents targeting the deregulated cell cycle has been considered as an ideal strategy for cancer therapy. Cdc25 phosphatase inhibitors, which are cell cycle-based agents, inhibit the proliferation of many types of tumor cells by causing cell cycle arrest. Many of the most potent $\mathrm{Cdc} 25$ phosphatase inhibitors reported to date are quinonoid compounds. PM contains copious anthraquinone compounds, thus we assumed that PME may inhibit Cdc25 phosphatases to cause anti-proliferation activity in cancer cells.

The aim of this study was to investigate the roles of PME in cell cycle distribution and cell apoptosis in MCF-7 human breast cancer cells and its underlying mechanisms. We revealed that PME inhibits the proliferation of MCF-7 cells by arresting the cell cycle in the G2/M phase and by promoting cell apoptosis. The effects are mainly mediated by inhibition of Cdc25 phosphatases and modulation of the bax-dependent apoptotic pathway.

\section{Materials and methods}

Materials. PM was obtained from the Harbin branch of Peking Tong Ren Tang TCM Co., Ltd. (Harbin, China). Antibodies against Cdc25B, Cdc25C, cyclin B1, Cdk1, phospho-Cdk1 (p-Cdk1, Tyr15), bcl-2-associated X protein (bax), bcl-2, cytochrome c, cleaved caspase-9 (Asp315, $35 \mathrm{kDa}$ ) and $\beta$-actin were purchased from Cell Signaling Technology, Inc. (Beverly, MA, USA). Annexin V-FITC kit, propidium iodide (PI) and RNase A were purchased from Sigma Chemical Co. (St. Louis, MO, USA). The BCA protein assay kit was purchased from Pierce Biotechnology, Inc. (Rockford, IL, USA) and the BCIP/NBT Alkaline Phosphatase Color Development kit was purchased from Sangong Biotech Co., Ltd. (Shanghai, China). All of the other reagents were of analytical grade.

Preparation of PME. The dried crude root of PM $(10 \mathrm{~g})$ was cut into small pieces and ground into coarse powder that passed through a 20 -mesh $(0.9-\mathrm{mm})$ sieve and extracted with $50 \%$ ethanol $(200 \mathrm{ml})$ and agitated continuously on a rocker platform at $30^{\circ} \mathrm{C}$ for $20 \mathrm{~h}$. After centrifugation at $8,000 \mathrm{rpm}$ for $15 \mathrm{~min}$, the supernatant was concentrated to obtain a brown powder $(182 \mathrm{mg})$ under reduced pressure by a rotary evaporator and stored at $-20^{\circ} \mathrm{C}$. PME was dissolved in dimethyl sulfoxide (DMSO) at a concentration of $2 \mathrm{mg} / \mathrm{ml}$ prior to the experiments.

Cell lines. The MCF-7 human mammary epithelial cell line was purchased from the cell bank of the Shanghai Institute of Biological Sciences, Chinese Academy of Sciences. MCF-7 cells were routinely cultured in RPMI-1640 supplemented with $10 \%$ fetal bovine serum (FBS) and $1 \%$ penicillin streptomycin solution at $37^{\circ} \mathrm{C}$ in an atmosphere of $95 \%$ air and $5 \% \mathrm{CO}_{2}$ in a humidified incubator. Cell cycle was synchronized at G0 phase by incubation in FBS-free RPMI-1640 for $16 \mathrm{~h}$, followed by washing with phosphate-buffered saline (PBS) and fresh medium replacement when the experiments concerning cell cycle were performed.

Proliferation assay. MCF-7 cells were seeded in 96-well microtiter plates at a density of $1 \times 10^{4}$ cells/well in $200 \mu \mathrm{l}$ medium; the medium was replaced the following morning with $200 \mu \mathrm{l}$ of fresh complete medium containing PME of different final concentrations. Cells were treated with PME for different times according to the experimental requirement, using DMSO as vehicle at a maximum concentration of $0.1 \%$. After PME treatment, MTT solution $(5 \mathrm{mg} / \mathrm{ml}, 20 \mu \mathrm{l}$, final concentration $0.5 \mathrm{mg} / \mathrm{ml}$ ) in RPMI-1640 without FBS was added to every well for $4 \mathrm{~h}$ at $37^{\circ} \mathrm{C}$. Dark blue formazan crystals forming in the intact cells were dissolved with DMSO for 10 min on a rocker platform, and the absorbance was measured at $570 \mathrm{~nm}$ using an ELISA reader (Tecan Sunrise, Switzerland). The results were then expressed as percentages of MTT reduction, with the absorbance exhibited by the control cells being arbitrarily set as $100 \%$. The inhibitory rate was calculated according to: (OD control - OD sample)/OD control x 100\%.

Flow cytometry (FCM). The effect of PME on cell cycle distribution was determined by FCM after staining the cells with PI. Briefly, $5 \times 10^{5}$ cells were seeded in $25-\mathrm{cm}^{2}$ culture flasks and allowed to attach for $6 \mathrm{~h}$ of incubation and FBS-free medium replacement overnight. The medium was replaced with fresh complete medium containing PME at the desired concentrations. DMSO (final concentration $<0.1 \%$ ) was used as a negative control. After treatment for $24 \mathrm{~h}$ at $37^{\circ} \mathrm{C}$, floating and adherent cells were collected, washed with ice-cold PBS and fixed with $70 \%$ ethanol for at least $12 \mathrm{~h}$ at $44^{\circ} \mathrm{C}$. The cells were then treated with $80 \mathrm{mg} / \mathrm{ml}$ RNase A and $50 \mu \mathrm{g} / \mathrm{ml} \mathrm{PI} \mathrm{at} \mathrm{a}$ density of $1 \times 10^{6}$ cells $/ \mathrm{ml}$ for $30 \mathrm{~min}$, and the stained cells were analyzed using a BD FACS Calibur. Data acquisition $(10,000$ events for each sample) was performed using Cell Quest software (Becton Dickinson, USA).

The apoptotic rate was measured by FCM according to the instructions provided by the Annexin V-FITC kit. In brief, following treatment with PME, cells were harvested after digestion with $0.25 \%$ trypsin, washed three times with ice-cold PBS containing calcium and resuspended in binding buffer $(500 \mu \mathrm{l})$ at a concentration of $1 \times 10^{6} \mathrm{cells} / \mathrm{ml}$, in which $500 \mu \mathrm{l}$ of cell suspension was added to a $5-\mathrm{ml} \mathrm{FCM} \mathrm{tube.}$ Annexin V-FITC $(50 \mu \mathrm{g} / \mathrm{ml}, 5 \mu \mathrm{l})$ and PI $(50 \mu \mathrm{g} / \mathrm{ml}, 5 \mu \mathrm{l})$ were added, and incubation was carried out for $30 \mathrm{~min}$ at room temperature in the dark. Quantitative analysis of the apoptotic level was performed using FCM. The apoptotic percentage of 10,000 cells was determined.

Transmission electron microscopy (TEM). MCF-7 cells were seeded at a density of $1 \times 10^{6}$ cells/flask and treated with DMSO or PME-supplemented medium for $48 \mathrm{~h}$. At the end of the incubation period, cells were fixed with $2.5 \%$ glutaraldehyde in $0.1 \mathrm{M}$ sodium cacodylate buffer for $24 \mathrm{~h}$ at $4^{\circ} \mathrm{C}$. Then, the cells were washed in the same buffer three times, fixed with $1 \%$ osmium tetroxide and dehydrated in graded ethanol. The $100 \%$ ethanol solution was then replaced by propylene oxide 
and embedded in epoxy resin, which was polymerized at $70^{\circ} \mathrm{C}$ for $8 \mathrm{~h}$. Sections were stained with uranyl acetate and lead citrate, and then observed with a Hitachi H-7650 TEM.

Western blotting. The expression levels of Cdc25B, Cdc25C, cyclin B1, Cdk1, p-Cdk1, bax, bcl-2, cytochrome c, cleaved caspase- 9 and $\beta$-actin were detected by Western blotting, with specific antibodies against these proteins.

MCF-7 cells $\left(5 \times 10^{5}\right)$ were seeded in $25-\mathrm{cm}^{2}$ culture flask for $6 \mathrm{~h}$ to be adherent, using the same procedure for cell synchronizing. After PME treatment, cells were washed three times in ice-cold PBS and lysed with $200 \mu \mathrm{l}$ lysis buffer containing $1 \%$ Triton X-100, $0.5 \%$ sodium deoxycholate, $0.5 \mathrm{mg} / \mathrm{ml}$ leupetin, $1 \mathrm{mM}$ EDTA, $1 \mathrm{mg} / \mathrm{ml}$ pepstatin and $0.2 \mathrm{mM}$ phenylmethylsulfonyl fluoride (PMSF). After the cells had been incubated on ice for $30 \mathrm{~min}$ and scraped from the flasks, the lysates were centrifuged at 5,000 $\mathrm{rpm}$ for $15 \mathrm{~min}$ to discard the precipitate. Protein concentrations were determined using the BCA protein assay kit. Total cellular proteins $(20 \mu \mathrm{g})$ were separated by $12 \%$ SDS-polyacrylamide gel electrophoresis (PAGE) and transferred onto polyvinylidene difluoride (PVDF) membranes. The membranes were blocked with $5 \%$ nonfat dry milk and $0.05 \%$ Tween-20 in Tris-buffered saline (TBS) for $45 \mathrm{~min}$, and subsequently incubated with the primary antibody in TBS for $1 \mathrm{~h}$ at room temperature. The antibody-antigen complexes were then detected using alkaline phosphatase-conjugated anti-rabbit or anti-mouse IgG secondary antibodies, followed by the use of a BCIP/NBT Alkaline Phosphatase Color Development kit. The band was recorded by a digital camera and analyzed using ImageJ software (NIH, USA), normalized with the gray value of $\beta$-actin.

For cytochrome c determination, $5 \times 10^{7}$ cells were suspended in five volumes of $20 \mathrm{mM}$ HEPES (pH 7.5), $10 \mathrm{mM}$ $\mathrm{KCl}, 1.5 \mathrm{mM} \mathrm{MgCl} 2,1 \mathrm{mM}$ EDTA, $1 \mathrm{mM}$ EGTA, $1 \mathrm{mM}$ DTT, $0.1 \mathrm{mM}$ PMSF and $10 \mathrm{mM}$ leupeptin containing $20 \mathrm{mM}$ sucrose. The cells were disrupted by stroking in a glass homogenizer. The nuclei were centrifuged at $1,000 \mathrm{xg}$ for $10 \mathrm{~min}$ at $4^{\circ} \mathrm{C}$. The resulting supernatant was centrifuged at $10,000 \times \mathrm{g}$ for $30 \mathrm{~min}$ to pellet mitochondria. A final centrifugation at $100,000 \mathrm{x}$ for $1 \mathrm{~h}$ at $4^{\circ} \mathrm{C}$ generated the cytoplasmic fraction.

Statistical analysis. All of the experiments were performed three times and data were expressed as the means \pm standard deviation (SD) and analyzed by SPSS using the Student's t-test. In all cases, a value of $\mathrm{P}<0.05$ was considered statistically significant.

\section{Results}

Effect of PME on MCF-7 cell proliferation. In order to evaluate the effect of PME on the proliferation of MCF-7 cells, the cells were treated with increasing concentrations of PME for different times. PME inhibited the growth of MCF-7 cells in a dose- and time-dependent manner (Fig. 1). $\mathrm{IC}_{50}$ values of PME $(24 \mathrm{~h}, 200.3 \pm 12.3 \mu \mathrm{g} / \mathrm{ml} ; 48 \mathrm{~h}, 146.8 \pm 4.4 \mu \mathrm{g} / \mathrm{ml} ; 72 \mathrm{~h}$, $113.2 \pm 6.6 \mu \mathrm{g} / \mathrm{ml})$ were obtained by extrapolation from the linear regression analysis.

Effect of PME on cell cycle arrest. We designed experiments to determine whether PME-mediated suppression of MCF-7

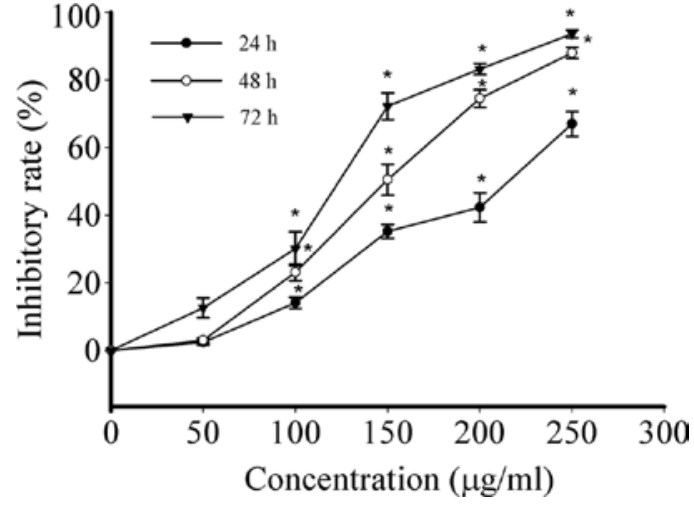

Figure 1. Effect of PME on the proliferation of MCF-7 cells. MCF-7 cells were exposed to increasing dosages of PME (50, 100, 150, 200 and $250 \mu \mathrm{g} /$ $\mathrm{ml}$ ) with fresh medium for a total of 24,48 or $72 \mathrm{~h}$. Values are expressed as the percentage of control group (DMSO). Values are the means $\pm S D ; n=6$. Data are representative of three independent experiments. "Different from the vehicle control, $\mathrm{P}<0.05$.

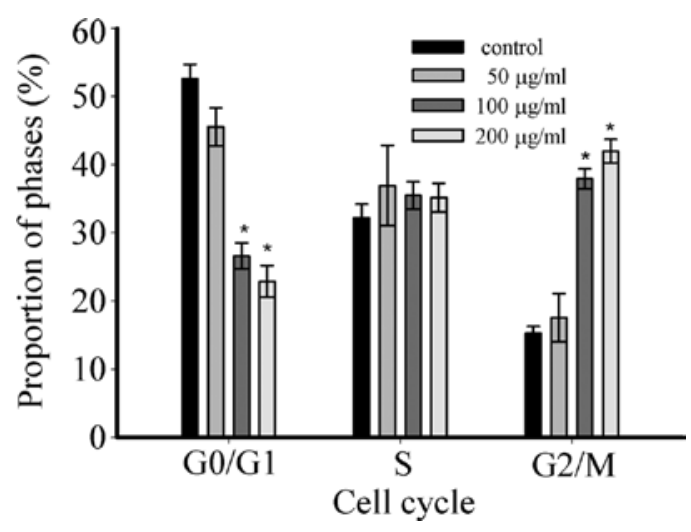

Figure 2. Effect of PME on MCF-7 cell-cycle progression. Synchronized MCF-7 cells were subjected to PME of increasing concentrations (50, 100 and $200 \mu \mathrm{g} / \mathrm{ml}$ ) for $24 \mathrm{~h}$. The cells were stained with PI and analyzed for DNA content by FCM to determine the percentages of cells in the G0/G1, $\mathrm{S}$ and $\mathrm{G} 2 / \mathrm{M}$ phases of the cell cycle. Data are the means \pm SD from three independent experiments. Columns, mean ( $\mathrm{n}=3$ ); bars, SD. ${ }^{*} \mathrm{P}<0.05$ compared to the control group treated with DMSO.

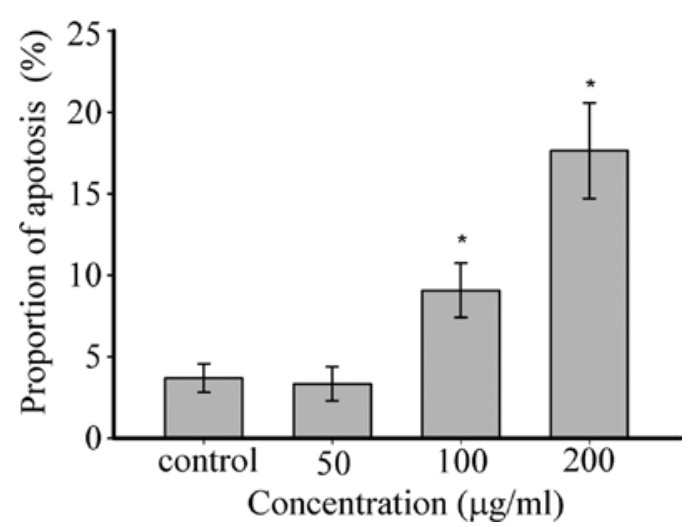

Figure 3. Effect of PME on apoptosis in MCF-7 cells. MCF-7 cells were subjected to PME of increasing concentrations (50, 100 and $200 \mu \mathrm{g} / \mathrm{ml}$ ) for $48 \mathrm{~h}$. Analysis of the presence of phosphatidylserine on the outer leaflet of the cell membrane was performed using a double-labeling experiment with Annexin V-FITC and PI to discriminate apoptotic from necrotic cells. Approximately 9 and $18 \%$ of apoptotic cells were detected in MCF-7 cell lines treated with 100 and $200 \mu \mathrm{g} / \mathrm{ml}$ PME, respectively. Data are the means \pm SD from three independent experiments. Columns, mean $(n=3)$; bars, SD. ${ }^{*} \mathrm{P}<0.05$ compared to the control group treated with DMSO. 
A

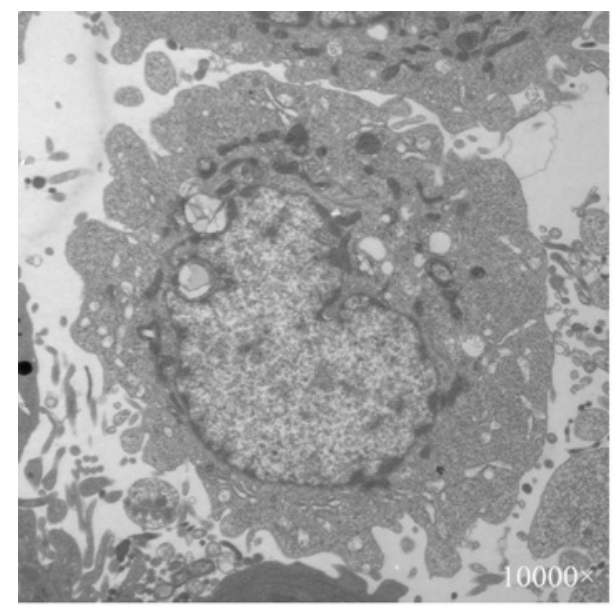

C

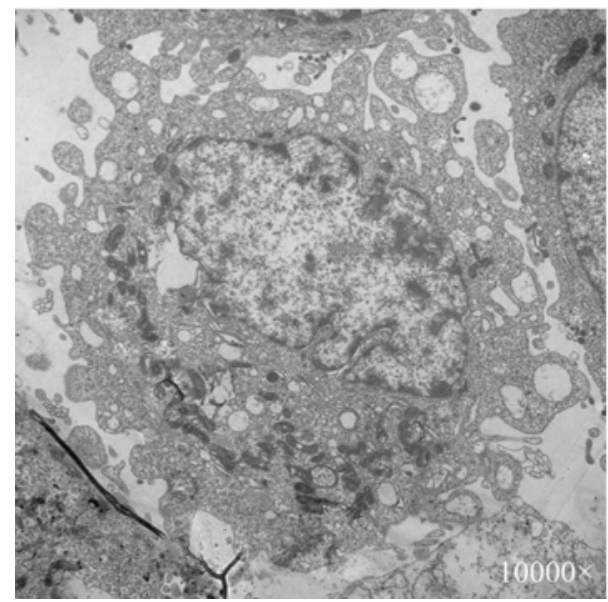

B

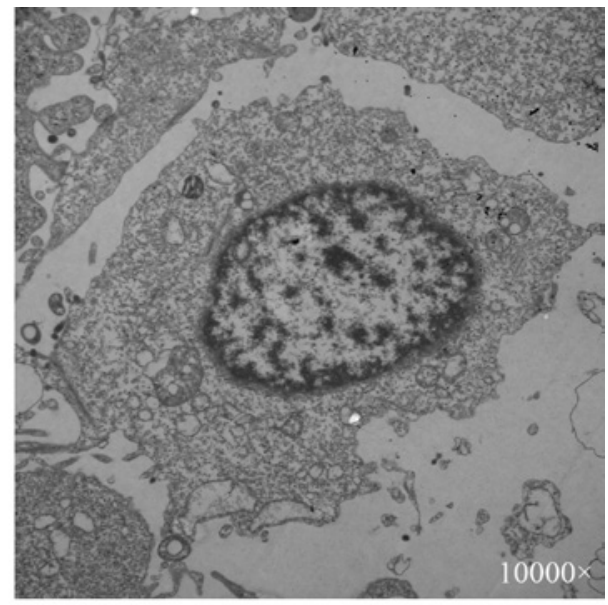

D

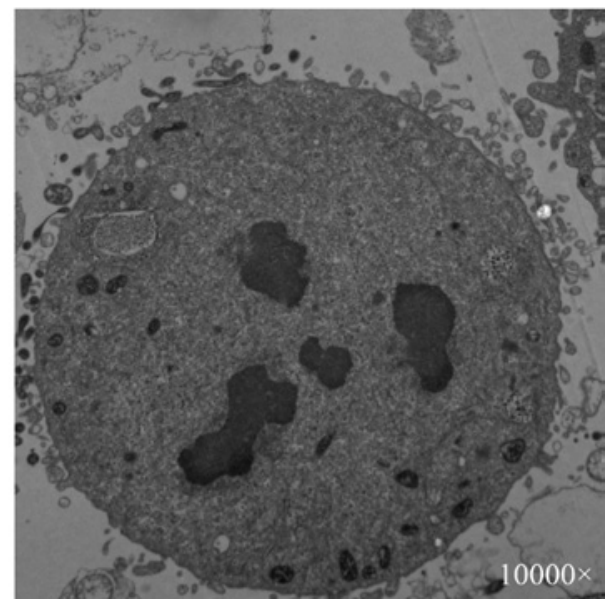

Figure 4. Morphology of MCF-7 cells analyzed by TEM. MCF-7 cells were treated with $150 \mu \mathrm{g} / \mathrm{ml} \mathrm{PME}$ for $48 \mathrm{~h}$ and then examined by TEM at magnification $\mathrm{x} 10,000$. (A) In the control cells, the structure of the nucleus, abundance of cytoplasm, as well as the size and shape of the mitochondria, were normal. (B) In the treated cells, the compaction and margination of nuclear chromatin were quite obvious. (C) Cell detachment, cell shrinkage, folded nuclear membrane, membrane blebbing, increased nuclear heterochromatin, swelling of the endoplasmic reticulum cisternae and vesicle formation (abundant vacuoles with multivesicular bodies) were observed. (D) Nuclear pyknosis and fragmentation occurred.

cell proliferation correlated with cell cycle arrest. As shown in Fig. 2, after a 24-h treatment of MCF-7 cells with increasing dosages of PME, FCM assay showed that the proportions of cells in the $\mathrm{G} 2 / \mathrm{M}$ phase were $15.3 \pm 1.00,17.6 \pm 3.55,37.9 \pm 1.47$ and $42.0 \pm 1.71 \%$ after $0,50,100$ and $200 \mu \mathrm{g} / \mathrm{ml}$ of PME, respectively. PME resulted in a significant increase in the cells in the $\mathrm{G} 2 / \mathrm{M}$ phase and a decrease in the $\mathrm{G} 0 / \mathrm{G} 1$ phase in a dosedependent manner.

Effect of PME on cell apoptosis. In order to determine whether the addition of PME induced cell apoptosis, FCM and TEM were conducted in PME-treated MCF-7 cells and the control. FCM showed that the cell apoptotic rates were 9.1 \pm 1.67 and $17.7 \pm 2.93$ after treatment with 100 and $200 \mu \mathrm{g} / \mathrm{ml}$ PME for $48 \mathrm{~h}$, respectively. MCF-7 cells treated with increasing concentrations of PME exhibited a statistically significant increase in the apoptotic cell fraction, indicating apoptosis induction (Fig. 3).

Morphological and ultrastructural changes in MCF-7 cells exposed to PME for $48 \mathrm{~h}$ were examined by TEM (Fig. 4). In the treated cells, characteristics of apoptosis were noted.

Effect of PME on the cell cycle and apoptosis regulatory protein expression. Western blots of the effect of PME treatment on the levels of proteins involved in the regulation of G2-M transition are shown in Fig. 5A. The levels of Cdc25B, Cdc25C and Cdk1 proteins were reduced markedly in the treated cells compared to the control. The decreased level of Cdc25B was not significant compared to that of $\mathrm{Cdc} 25 \mathrm{C}$. PME treatment caused a statistically significant increase in the protein level of p-Cdk1. A change in cyclin B1 was not detected in the MCF-7 cells.

To determine which type of apoptotic pathway was induced by PME, lysates from the MCF-7 cells after PME treatment for $48 \mathrm{~h}$ were examined by Western blotting using bax-, bcl-2-, cytochrome c- and cleaved caspase-9-specific antibodies (Fig. 5B). Our results clearly demonstrated an increase in the bax protein content in the MCF-7 cells treated with different concentrations of PME, suggesting that PME induces apoptosis in MCF-7 cells likely via a bax-dependent pathway. A change in the anti-apoptotic protein bcl-2 was never detected under any conditions. We then examined whether the expression of bax promoted the release of mitochondrial cytochrome $\mathrm{c}$ into the cytosol leading to activation of the caspase cascade that is essential for the death program. Fig. 5B shows that as the level of bax increased, cytochrome c was detected in the cytoplasm, whereas its level in the mitochondria decreased. Finally, the caspase cascade was also induced by PME, as shown by the cleavage of caspase- 9 . 
A

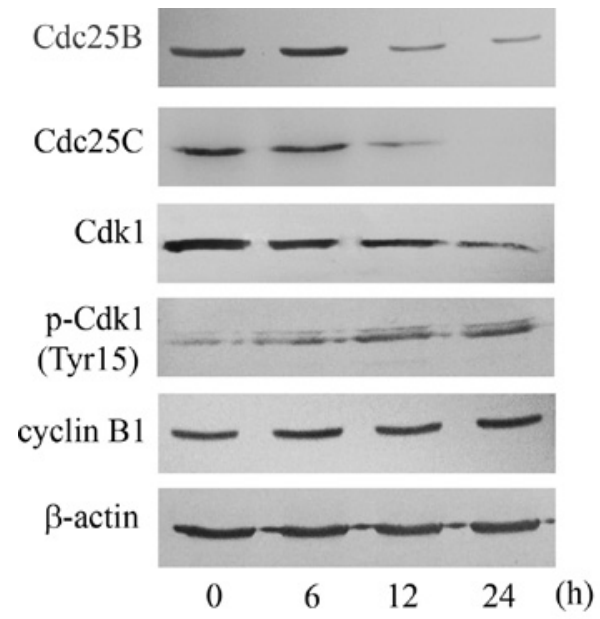

B
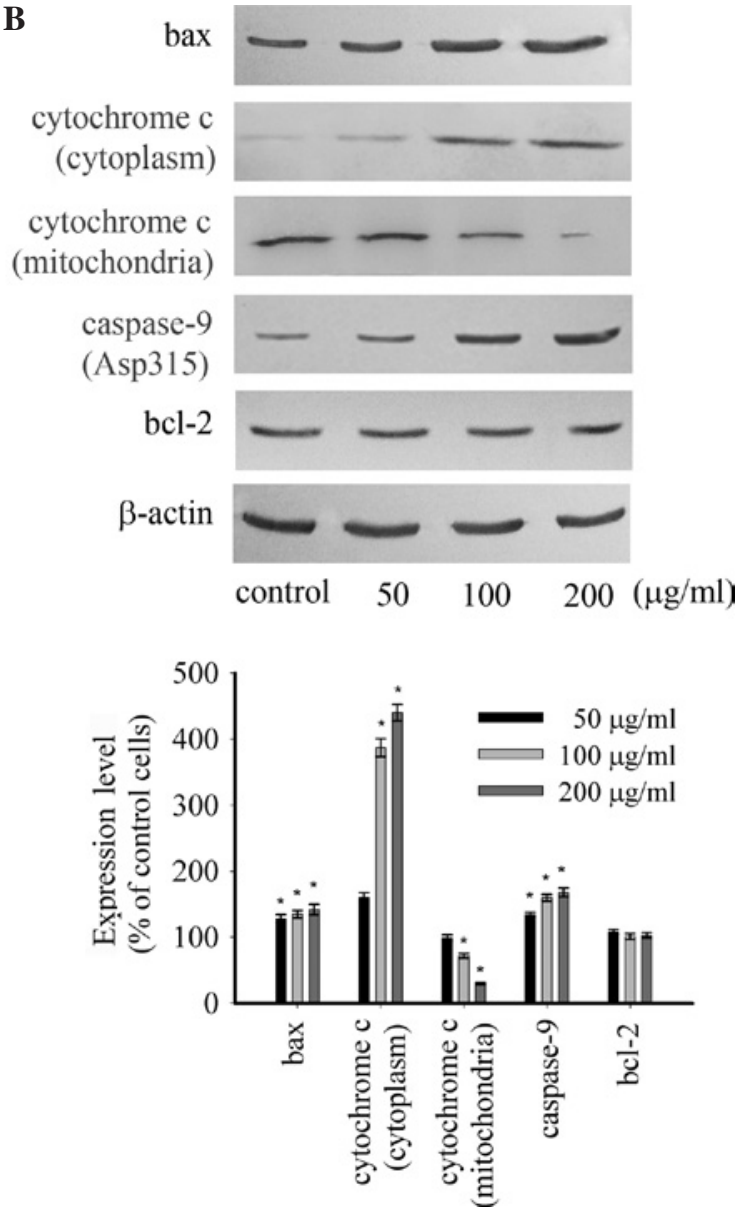

Figure 5. Change in protein expression levels in the MCF-7 cells treated by PME. (A) Western blotting for Cdc25B, Cdc25C, Cdk1, p-Cdk1 and cyclin B1 using lysates from MCF-7 cells treated with $150 \mu \mathrm{g} / \mathrm{ml}$ PME for 0, 6, 12 and $24 \mathrm{~h}$. Proteins (20 $\mu \mathrm{g})$ were separated by SDS-PAGE and probed with the indicated antibodies. (B) Western blotting for bax, bcl-2, cytochrome $\mathrm{c}$ and cleaved caspase-9 using lysates from MCF-7 cells treated with PME at various concentrations $(50,100$ and $200 \mu \mathrm{g} / \mathrm{ml})$ for $48 \mathrm{~h}$. The gray values were determined and analyzed by the ImageJ software package, normalized with the gray value of $\beta$-actin. Data are presented as the means \pm SD from three repeated tests. " $\mathrm{P}<0.05$ compared to the control group treated with DMSO.

\section{Discussion}

Phosphorylation and dephosphorylation of proteins mediated by protein kinases and phosphatases are a core component of cellular regulation and signal transduction (14). Currently, multiple phosphatases have been determined to be involved in tumorigenesis and development: protein phosphatase $2 \mathrm{~A}$ (PP2A), Cdc25 phosphatases (Cdc25A, Cdc25B and Cdc25C), phosphatase of regenerating liver-3 (PRL-3) and phosphatase and tensin homologue deleted on chromosome 10 (PTEN) (15-18). Eukaryotic cell cycle progression involves sequential activation of Cdks, whose activity is dependent on their dephosphorylation status mediated by Cdc25 phosphatases. The G2-M transition and entry into mitosis is mainly regulated by cyclin B1/Cdk1 complex activity, which is negatively regulated by reversible phosphorylations at Thr14 and Tyr15 of Cdk1 during the G2/M phase (19). Cdc25 phosphatases stimulate cell cycle progression by activating cyclin $\mathrm{B} 1 / \mathrm{Cdk}$ complexes by catalyzing the removal of phosphate from the Cdk proteins, and the reaction is believed to be a rate-limiting step for entry into mitosis $(20,21)$. Most previous studies indicate that each $\mathrm{Cdc} 25$ homolog controls distinct aspects of cell cycle progression, namely non-overlapping roles for each isoform during a specific cell cycle phase. Briefly, Cdc25A is important for entry into S-phase, whereas Cdc25B is essential for pre-initiating G2-M transition and progression of S-phase. Cdc25C dephosphorylates and activates cyclin B1/Cdk1 (22). However, recent evidence suggests that multiple $\mathrm{Cdc} 25$ isoforms cooperate to control each cell cycle transition. All three Cdc25 isoforms play essential roles during the G1-S and G2-M transitions, and in mitosis, where they show specific activity towards Cdk1/cyclin B1 $(23,24)$. Certain quinonederived compounds, which were identified as Cdc25 inhibitors, may cause cell cycle arrest and inhibit tumor cell proliferation markedly. Therefore, development of Cdc25 inhibitors has been considered as a promising strategy for cancer therapy. Cdc25 inhibitor BN-82685 is active in vivo and inhibits the growth of human pancreatic tumor Mia PaCa-2 cells xenografted into athymic nude mice (25). Another Cdc25 inhibitor, ARQ-501, has undergone phase I clinical trials in patients with advanced and chemotherapy-unresponsive solid tumors, and is undergoing a phase II trial in patients with leimyosarcoma and head and neck cancer (26). These Cdc25 inhibitors have demonstrated pre-clinical efficacy, but their efficacy in the clinic has been modest and has been hampered by various side effects (26). Accordingly, preparation and evaluation of 
a new Cdc25 inhibitor with potent efficacy and minor side effects would have great interest in the therapeutics of human malignant tumors. Choi et al reported that anthraquinones isolated from PM have potent inhibitory activities on $\mathrm{Cdc} 25 \mathrm{~B}$ and anti-proliferation effects on human colon cancer SW620 cells, while the inhibitory activities on $\mathrm{Cdc} 25 \mathrm{C}$ have not been detected (12).

In the present study, we initially discovered that PME inhibited the proliferation of MCF-7 cells by arresting the cell cycle in the $\mathrm{G} 2 / \mathrm{M}$ phase, so we assumed that the effectiveness may be mediated by inhibition of Cdc25B and/or Cdc25C phosphatases. The present study showed that the inhibitory activity on Cdc25C by PME was noticeable compared to Cdc25B. We also found that PME caused a sustained decrease in Cdk1, $\mathrm{Cdc} 25 \mathrm{~B}$ and $\mathrm{Cdc} 25 \mathrm{C}$ expression and an increase in $\mathrm{p}-\mathrm{Cdk} 1$ expression at $24 \mathrm{~h}$. These results suggest that PME treatment may cause inactivation of Cdk1 possibly due to a decrease in the level of Cdk1 protein; an increase in $\mathrm{p}-\mathrm{Cdk} 1$ resulted from attenuation of dephosphorylation of Cdk1 which is catalyzed by $\mathrm{Cdc} 25$ phosphatases. These PME-induced modulations of $\mathrm{G} 2 / \mathrm{M}$ regulatory protein expression may contribute to the PME-induced G2/M arrest in MCF-7 cells.

Our result also showed that PME-induced MCF-7 cell apoptosis was accompanied by an overexpression of bax. Bax acting as a promoter of cell apoptosis is a protein present predominantly in the cytoplasm, which binds with the outer membrane of the mitochondrion and is capable of forming a selective ion channel (mitochondrial permeability transition pore: PT pore) in membranes, a critical event in the loss of cell viability that mediates the release of cytochrome c, finally activating the caspase cascade (27-29). Previous studies have shown that the activation of the caspase cascade is involved in apoptosis (30). Caspases which exist as inactive pro-caspases are proteolytically activated via multiple cleavages in cells undergoing apoptosis (31). Then, the activated caspases cleave specific substrates, including poly (ADP-ribose) polymerase, lamin and focal adhesion kinase, resulting in the apoptosis of cells (32). In our study, overexpression of the bax protein was correlated with cytochrome c release, suggesting it triggers caspase-dependent apoptosis. This was evidenced by the presence of active caspase-9, and the cleavage of it was up-regulated by increasing dosages of PME in the treated cells. In contrast, the PM extract was found to protect human umbilical vein endothelial cells from the inflammatory factor TNF- $\alpha$ which causes apoptotic damage, accompanied by down-regulation of caspase-3 gene expression (33). Tetrahydroxystilbene glucoside extracted from PM has protective effects against MPP(+)induced apoptosis in PC12 cells mediated via the inhibition of reactive oxygen species generation and modulation of JNK activation (34). Taken together with these studies, our results indicated that the responses of tumor cells and non-tumor cells to PME may be different.

In summary, the present study demonstrated that PME inhibited MCF-7 cell proliferation by inducing cell cycle arrest in the G2/M phase and promoting cell apoptosis. These PME-induced responses are associated with changes in expression and activity of cell cycle regulatory proteins and apoptosis proteins. It will now be of substantial interest to determine the nature of PME interaction with cellular targets responsible for triggering mitotic cell cycle arrest to develop antitumor drugs from PM.
A major concern of scientists investigating herbal treatments is that the chemical compositions contained in the herbs contributing to their biological effects are largely unknown. PME is an admixture comprising many compounds, while the constituent contributing to the main effect remains unknown. Further studies are therefore required to assess the efficacies of the components of this herb on antitumor and possible adverse side effects. The precise mechanisms of cell-cycle arrest and apoptosis caused by PME warrant subsequent investigation.

\section{Acknowledgements}

This study was supported by the Technological Innovation Project of Harbin Science and Technology Bureau (no. 2011RFQYS073), the Specialized Research Fund for the Doctoral Program of Higher Education (no. 20092307110019), the Project of Heilongjiang Education Bureau (no. 11531117) and the Returned Overseas Scholars Science Fund of Heilongjiang (no. LC201009), P.R. China.

\section{References}

1. Brower V: Back to nature: extinction of medicinal plants threatens drug discovery. J Natl Cancer Inst 100: 838-839, 2008.

2. XiaoPG, Xing ST and Wang LW:Immunological aspects of Chinese medicinal plants as antiageing drugs. J Ethnopharmacol 38: 167-175, 1993.

3. Yang PY, Almofti MR, Lu L, et al: Reduction of atherosclerosis in cholesterol-fed rabbits and decrease of expression of intracellular adhesion molecule-1 and vascular endothelial growth factor in foam cells by a water-soluble fraction of Polygonum multiflorum. J Pharmacol Sci 99: 294-300, 2005.

4. Chan E, Wong CY, Wan CW, et al: Evaluation of anti-oxidant capacity of root of Scutellaria baicalensis Georgi, in comparison with roots of Polygonum multiflorum Thunb and Panax ginseng CA Meyer. Am J Chin Med 38: 815-827, 2010.

5. Lin LC, Nalawade SM, Mulabagal V, Yeh MS and Tsay HS: Micropropagation of Polygonum multiflorum Thunb and quantitative analysis of the anthraquinones emodin and physcion formed in in vitro propagated shoots and plants. Biol Pharm Bull 26: 1467-1471, 2003.

6. Yi T, Leung KS, Lu GH, Zhang $\mathrm{H}$ and Chan K: Identification and determination of the major constituents in traditional Chinese medicinal plant Polygonum multiflorum Thunb by HPLC coupled with PAD and ESI/MS. Phytochem Anal 18: 181-187, 2007.

7. Chen Y, Wang M, Rosen RT and Ho CT: 2,2-Diphenyl-1picrylhydrazyl radical-scavenging active components from Polygonum multiflorum Thunb. J Agric Food Chem 47: 2226-2228, 1999.

8. Wang X, Zhao L, Han T, Chen S and Wang J: Protective effects of 2,3,5,4'-tetrahydroxystilbene-2-O-beta-d-glucoside, an active component of Polygonum multiflorum Thunb, on experimental colitis in mice. Eur J Pharmacol 578: 339-348, 2008.

9. Ho TY, Wu SL, Chen JC, Li CC and Hsiang CY: Emodin blocks the SARS coronavirus spike protein and angiotensin-converting enzyme 2 interaction. Antiviral Res 74: 92-101, 2007.

10. Um MY, Choi WH, Aan JY, Kim SR and Ha TY: Protective effect of Polygonum multiflorum Thunb on amyloid beta-peptide 25-35 induced cognitive deficits in mice. J Ethnopharmacol 104: $144-148,2006$.

11. Xu ML, Zheng MS, Lee YK, et al: A new stilbene glucoside from the roots of Polygonum multiflorum Thunb. Arch Pharm Res 29: 946-951, 2006.

12. Choi SG, Kim J, Sung ND, et al: Anthraquinones, Cdc25B phosphatase inhibitors, isolated from the roots of Polygonum multiflorum Thunb. Nat Prod Res 21: 487-493, 2007.

13. Rubinstein LV, Shoemaker RH, Paull KD, et al: Comparison of in vitro anticancer-drug-screening data generated with a tetrazolium assay versus a protein assay against a diverse panel of human tumor cell lines. J Natl Cancer Inst 82: 1113-1118, 1990.

14. Salazar $C$ and Hofer T: Competition effects shape the response sensitivity and kinetics of phosphorylation cycles in cell signaling. Ann NY Acad Sci 1091: 517-530, 2006. 
15. Li Y, Yue P, Deng X, et al: Protein phosphatase 2A negatively regulates eukaryotic initiation factor $4 \mathrm{E}$ phosphorylation and eIF4F assembly through direct dephosphorylation of Mnk and eIF4E. Neoplasia 12: 848-855, 2010.

16. Mizuno R, Oya M, Hara S, et al: Modulation of bcl-2 family proteins in MAPK independent apoptosis induced by a cdc25 phosphatase inhibitor Cpd 5 in renal cancer cells. Oncol Rep 14 639-644, 2005.

17. Choi MS, Min SH, Jung H, et al: The essential role of FKBP38 in regulating phosphatase of regenerating liver 3 (PRL-3) protein stability. Biochem Biophys Res Commun 406: 305-309, 2011.

18. Li Y, Su J, Dingzhang X, et al: PTEN deletion and heme oxygenase-1 overexpression cooperate in prostate cancer progression and are associated with adverse clinical outcome. J Pathol 224: 90-100, 2011.

19. Mueller PR, Coleman TR, Kumagai A and Dunphy WG: Myt1: a membrane-associated inhibitory kinase that phosphorylates Cdc2 on both threonine-14 and tyrosine-15. Science 270: 86-90, 1995.

20. Nilsson I and Hoffmann I: Cell cycle regulation by the Cdc25 phosphatase family. Prog Cell Cycle Res 4: 107-114, 2000.

21. Draetta G and Eckstein J: Cdc25 protein phosphatases in cell proliferation. Biochim Biophys Acta 1332: M53-M63, 1997.

22. Tamura K, Southwick EC, Kerns J, et al: Cdc25 inhibition and cell cycle arrest by a synthetic thioalkyl vitamin $\mathrm{K}$ analogue. Cancer Res 60: 1317-1325, 2000.

23. Lindqvist A, Kallstrom H, Lundgren A, Barsoum E and Rosenthal CK: Cdc25B cooperates with Cdc25A to induce mitosis but has a unique role in activating cyclin B1-Cdk1 at the centrosome. J Cell Biol 171: 35-45, 2005.

24. Busino L, Donzelli M, Chiesa M, et al: Degradation of Cdc25A by beta-TrCP during $\mathrm{S}$ phase and in response to DNA damage. Nature 426: 87-91, 2003.
25. Brezak MC, Quaranta M, Contour-Galcera MO, et al: Inhibition of human tumor cell growth in vivo by an orally bioavailable inhibitor of CDC25 phosphatases. Mol Cancer Ther 4: 1378-1387, 2005.

26. Contour-Galcera MO, Sidhu A, Prevost G, Bigg D and Ducommun B: What's new on CDC25 phosphatase inhibitors. Pharmacol Ther 115: 1-12, 2007.

27. Schafer B, Quispe J, Choudhary V, et al: Mitochondrial outer membrane proteins assist Bid in Bax-mediated lipidic pore formation. Mol Biol Cell 20: 2276-2285, 2009.

28. Jourdain A and Martinou JC: Mitochondrial outer-membrane permeabilization and remodelling in apoptosis. Int J Biochem Cell Biol 41: 1884-1889, 2009.

29. Riedl SJ and Shi Y: Molecular mechanisms of caspase regulation during apoptosis. Nat Rev Mol Cell Biol 5: 897-907, 2004.

30. Planey SL, Abrams MT, Robertson NM and Litwack G: Role of apical caspases and glucocorticoid-regulated genes in glucocorticoid-induced apoptosis of pre-B leukemic cells. Cancer Res 63 : 172-178, 2003.

31. Zhang W, He Q, Chan LL, et al: Involvement of caspases in 4-hydroxy-alkenal-induced apoptosis in human leukemic cells. Free Radic Biol Med 30: 699-706, 2001.

32. Widmann C, Gibson S and Johnson GL: Caspase-dependent cleavage of signaling proteins during apoptosis. A turn-off mechanism for anti-apoptotic signals. J Biol Chem 273 7141-7147, 1998

33. Ling S, Nheu L, Dai A, Guo Z and Komesaroff P: Effects of four medicinal herbs on human vascular endothelial cells in culture. Int J Cardiol 128: 350-358, 2008.

34. Li X,Li Y, Chen J, Sun J, Sun X and Kang X: Tetrahydroxystilbene glucoside attenuates $\mathrm{MPP}^{+}$-induced apoptosis in PC12 cells by inhibiting ROS generation and modulating JNK activation. Neurosci Lett 483: 1-5, 2010 . 